Revolutionary Horizons 


\section{Revolutionary Horizons}

Art and Polemics in 1950s Cuba

Abigail McEwen 
Copyright $\odot 2016$ by Abigail McEwen.

All rights reserved.

This book may not be reproduced, in whole or in part, including illustrations, in any form (beyond that copying permitted by Sections 107 and 108 of the U.S. Copyright Law and except by reviewers for the public press), without written permission from the publishers.

yalebooks.com/art

Designed by Leslie Fitch Typeset by Julie Allred, BW\&A Books, Inc.

Printed in China through Oceanic Graphic International, Inc.

Library of Congress Control Number: 2015952891 ISBN 978-0-300-21681-3

A catalogue record for this book is available from the British Library. This paper meets the requirements of ANSI/NISO Z39.48-1992 (Permanence of Paper).

10987654321

Jacket illustrations: (front) Mario
Carreño, Cielos del sur [Southern Skies], 1950 (detail of fig. 74); (back) Raúl Martínez, Flight Eight, 1955 (fig. 64)

Frontispiece: Luis Martínez Pedro, Untitled, from the series "Aguas territoriales," 1964 (detail of fig. 96) 